\title{
PILOCARPINE CONTENT AND MOLECULAR DIVERSITY IN JABORANDI
}

\author{
Sardul Singh Sandhu'; Ilka Nacif Abreu²; Carlos Augusto Colombo ${ }^{3}$; Paulo Mazzafera ${ }^{2 *}$ \\ ${ }^{1}$ Department of Biological Science, R. D. University, Jabalpur, India. \\ ${ }_{3}^{2}$ UNICAMP/IB - Depto. de Fisiologia Vegetal. C.P. 6109 - 13083-970 - Campinas, SP - Brasil. \\ ${ }^{3}$ IAC - Centro de Pesquisa e Desenvolvimento de Recursos Genéticos Vegetais, C.P. 28 - 13020-902 - Campinas, \\ SP - Brasil. \\ *Corresponding author <pmazza@unicamp.br>
}

\begin{abstract}
Pilocarpine is an imidazol alkaloid exclusively found in Pilocarpus genus and $P$. microphyllus accumulates its highest content in the leaves. There is no report in the literature on the variability of the pilocarpine content in this genus. A population of 20 genotypes of $P$. microphyllus from the state of Maranhão, Brazil, was analyzed for Random Amplification of Polymorphic DNA (RAPD) markers and pilocarpine content. Although it was not possible to establish any correlation between these features, the absence or presence of some markers could indicate in some genotypes a possible association with the content of the alkaloid.
\end{abstract}

Key words: RAPD, Pilocarpus jaborandi, molecular diversity, molecular markers

\section{CONTEÚDO DE PILOCARPINA E DIVERSIDADE MOLECULAR EMJABORANDI}

\begin{abstract}
RESUMO: Pilocarpina é um alcalóide imidazólico encontrado exclusivamente em plantas do gênero Pilocarpus, sendo que as folhas de P. microphyllus acumulam o maior conteúdo deste alcalóide. Não há na literatura nenhum relato sobre a variabilidade do conteúdo de pilocarpina nesse gênero. Uma população de 20 plantas de $P$. microphyllus do estado do Maranhão, Brasil, foi analisada por marcadores Aplicação de DNA polimórfico randomica (RAPD) e quanto ao conteúdo de pilocarpina. Apesar de não ter sido possível estabelecer uma associação entre as variáveis estudadas, a ausência ou a presença de alguns loci marcadores em certos genótipos puderam ser associados ao teor do alcalóide.

Palavras-chave: RAPD, Pilocarpus jaborandi, diversidade molecular, marcadores moleculares
\end{abstract}

\section{INTRODUCTION}

Pilocarpine is an imidazol alkaloid found in plants of the genus Pilocarpus. Plants of this genus are designated by the name jaborandi but only $P$. microphyllus, which accumulates the highest pilocarpine content, is considered the true jaborandi (Pinheiro, 1997; Vieira, 1999). Jaborandi grows as a shrub and it is found in the understorey of the preAmazonian rain forest and occurs more intensively in the state of Maranhão (Vieira, 1999; Pinheiro, 2002).

Pilocarpine has important pharmaceutical properties. It is used to reduce the intraocular pressure in the treatment of glaucoma (Migdal, 2000), as a stimulant of salivation and perspiration, and recently has been prescribed for the treatment of xerostomia, which is the reduction of saliva production (Davies et al., 2001).

In spite of the importance of the plant and the pharmacological activity of pilocarpine, only a few reports have been published on the content of this alka- loid in Pilocarpus (Andrade-Neto et al., 1996; Avancini et al., 2003). A preliminary study was carried out on the genetic diversity in jaborandi accessions using Random Amplification of Polymorphic DNA (RAPD) (Moura et al., 2003). Curiously, the highest genetic variability was observed within populations and not among populations. Pilocarpine was not determined in these plants.

The above-mentioned results prompted to the analysis of a population of P. microphyllus growing in a greenhouse which was obtained from seeds from a private farm in the Maranhão State, Brazil. Jaborandi is domesticated and is now cultivated as a crop, to our knowledge not having been submitted to any breeding program. Although having been explored in Brazil for three decades, only in $1989 / 90$ a program started to domesticate the plant. Domestication was accomplished from the knowledge accumulated by peasants, when all leaves involved in pilocarpine extraction were harvested from jaborandi plants in the forest. This 
know-how was mainly based on the observation that some collection areas contained plants with more pilocarpine than others and such plants presented larger leaflets. However, this might be related to soil fertility since the leaves containing higher contents were obtained from areas of pre-Amazonian rain forest while those with lower contents were either from 'cerrado' (Brazilian savanna) or areas along the coast (Pinheiro, 2002). Avancini et al. (2003) observed that nutrientdeprived jaborandi seedlings produced less pilocarpine in the leaves.

The plants growing in the greenhouse of this study presented different height, leaf shape, branch pattern and leaf color. Therefore, the aim was to investigate the content of pilocarpine in leaves of $20 \mathrm{ja}-$ borandi genotypes selected on the basis of their phenotypes, and try to establish a possible association with the genetic diversity revealed by molecular markers.

\section{MATERIAL AND METHODS}

\section{Plant material}

Seeds of Pilocarpus microphyllus Stapf. ex Holm. were germinated in vermiculite. A voucher specimen was deposited in the Herbarium of the State University of Campinas (UNICAMP) Campinas, SP State, Brazil. When the seedlings reached approximately $5 \mathrm{~cm}$ (five months old) they were transferred to 0.5 $\mathrm{L}$ plastic pots containing a mixture of sand and soil $(1: 1, \mathrm{v} / \mathrm{v})$ and each pot received complete nutrient solution $(50 \mathrm{~mL})$ twice a week (Hoagland \& Arnon, 1950). The 20 genotypes of this study were selected according to their height, branching pattern, leaflet size, and the color of young leaves. Two lateral leaflets positioned in the middle of the third composite leaf (from the apex) were harvested and one was used for extraction and the other for pilocarpine and anthocyanin determinations. The length of the selected leaf and leaflet were measured. Leaflets for chemical determinations were freeze-dried before extraction.

\section{Extraction and analysis procedures}

Pilocarpine was extracted and analysed by High Performance Liquid Chromatography (HPLC) using a standard method (Avancini et al., 2003). The absorbance of anthocyanins was determined in methanol extracts containing $1 \% \mathrm{HCl}$ prepared from the same amount of dried material (Rabino \& Mancinelli, 1986).

\section{DNA isolation and amplification}

Total genomic DNA was extracted from 0.3$0.4 \mathrm{~g}$ fresh leaves ground in liquid nitrogen using 0.1 $\mathrm{M}$ Tris- $\mathrm{HCl}, 1.25 \mathrm{M} \mathrm{NaCl}, 0.02 \mathrm{M}$ EDTA, $2 \%$ mixed alkyltrimethylammoniun bromide, and $1 \% \beta$ mercaptoethanol. After $90 \mathrm{~min}$ incubation at $65^{\circ} \mathrm{C}$ with slow stirring, the solution was treated twice with an equal volume of chloroform/isoamylalcohol (24:1) and the supernatant treated with RNAse. DNAs was precipitated with 0.8 vol. of isopropanol and after washing with $70 \%$ ethanol, it was vacuum dried and dissolved in $200 \mu \mathrm{L}$ of TE buffer. DNA was used in Polymerase Chain Reaction (PCR) reactions carried out in a $25 \mu \mathrm{L}$ reaction mixture containing $1 \mathrm{X}$ reaction buffer, $1.5 \mathrm{mM} \mathrm{MgCl} 2,10 \eta \mathrm{g}$ template DNA, $1.0 \mu \mathrm{M}$ primer, $100 \mu \mathrm{M}$ of each dNTP and 1 unit of Taq polymerase. The following conditions were used: $1 \mathrm{~min}$ at $94^{\circ} \mathrm{C}$, $1 \mathrm{~min}$ at $35^{\circ} \mathrm{C}$ and $1.5 \mathrm{~min}$ at $72^{\circ} \mathrm{C}$, repeated 42 times. Amplified fragments were separated on 1.5\% agarose gel and visualized with ethidium bromide. About 100 primers (Operon Technology, US) were tested for variation and polymorphism in 20 genotypes of the jaborandi tree.

\section{Data Analysis}

Only clearly amplified polymorphic fragments were analyzed. The RAPD fragments were scored as present (1) or absent (0) and these data used to calculate an index of genetic similarity between pairs of genotypes using the DICE coefficient of genetic similarity: $\mathrm{SD}=(2 a / n-d)$, were $a$ is the number of positive matches, $n$ is the sample size and $d$ is the number of negative matches. A hierarchical classification was obtained from these coefficients using the UPGMA method (unweighted pair-group method using arithmetical averages) of aggregation and bootstrap values. All statistical analysis were performed using NTSYSpc (Numerical Taxonomy and Mutivariate Analysis System for personal computers), version 2.1 software (Rohlf, 2000).

\section{RESULTS AND DISCUSSION}

The content of pilocarpine in the 20 genotypes was variable, and it was possible to separate them in four groups (Table 1). Group 1 was formed by genotypes containing less pilocarpine, with pilocarpine below $50 \mu \mathrm{g} \mathrm{g}^{-1}$ f.w. A second group was formed by genotypes $5,8,9,11,16,18$ and 20 with pilocarpine contents within the range 60 to $90 \mu \mathrm{g} \mathrm{g}^{-1}$ f.w. pilocarpine. Group 3, by genotypes 6,14,15 and 19 with pilocarpine within the range $100-200 \mu \mathrm{g} \mathrm{g}^{-1}$ f.w. and the group 4 with three genotypes containing more than $200 \mu \mathrm{g} \mathrm{g}^{-1}$ f.w. pilocarpine in the leaves.

There are few reports in the literature to have this data compared. The amounts observed in the 20 genotypes are in agreement with previous values reported for jaborandi plants grown in greenhouse (Avancini et al., 2003). Plants in the field seem to accumulate more pilocarpine, with a mean values between 
Table 1 - Pilocarpine, anthoyanin and leaf/leaflet length of the 20 tree genotypes of P. microphyllus grouped according the alkaloid content.

\begin{tabular}{|c|c|c|c|c|c|}
\hline \multirow{2}{*}{ Tree genotype } & \multirow{2}{*}{ Group } & \multirow{2}{*}{ Pilocarpine } & \multirow{2}{*}{ Anthocyanin $($ Abs $\times 1000)$} & \multicolumn{2}{|c|}{ length } \\
\hline & & & & Leaf & Leaflet \\
\hline \multicolumn{4}{|c|}{$\mu \mathrm{g} \mathrm{g}^{-1}$ dry weight } & \multicolumn{2}{|c|}{ - - - - } \\
\hline 4 & 1 & 16.3 & 38 & 7.1 & 1.8 \\
\hline 17 & 1 & 19.8 & 16 & 5 & 1.1 \\
\hline 12 & 1 & 24.1 & 1 & 7 & 2.5 \\
\hline 3 & 1 & 24.1 & 77 & 8.5 & 2.5 \\
\hline 10 & 1 & 29.6 & 262 & 6.5 & 1.6 \\
\hline 13 & 1 & 39.4 & 52.0 & 11.1 & 2.5 \\
\hline 11 & 2 & 63.8 & 66 & 10.3 & 1 \\
\hline 8 & 2 & 67.5 & 113 & 9.5 & 2.5 \\
\hline 5 & 2 & 71.8 & 222 & 11.5 & 3 \\
\hline 16 & 2 & 74 & 36 & 8.5 & 1.5 \\
\hline 18 & 2 & 84.5 & 87 & 7.1 & 2 \\
\hline 20 & 2 & 85 & 51 & 9.1 & 2 \\
\hline 9 & 2 & 86.4 & 172 & 11.2 & 3.2 \\
\hline 14 & 3 & 129 & 55 & 12.4 & 2.5 \\
\hline 15 & 3 & 130.2 & 41 & 11.8 & 3.1 \\
\hline 19 & 3 & 145.1 & 52.0 & 10 & 2.6 \\
\hline 6 & 3 & 166.1 & 220 & 10.5 & 2.5 \\
\hline 2 & 4 & 215.7 & 620 & 7.8 & 2.3 \\
\hline 1 & 4 & 232.5 & 148 & 10.3 & 1.5 \\
\hline 7 & 4 & 235.9 & 589 & 8 & 2 \\
\hline
\end{tabular}

400-500 $\mu \mathrm{g} \mathrm{g}^{-1}$ (Sousa et al., 1991; Pinheiro, 1997; 2002), indicating that the content of pilocarpine might respond to environmental conditions. Indeed, it has been shown that secondary metabolites may have their concentration in plants strongly affected by biotic and abiotic factors (Waller \& Novack, 1978; Dixon \& Paiva, 1995). Avancini et al. (2003) observed that mineral, salt and oxygen stresses affect the content of pilocarpine in jaborandi leaves. In the evolution process mutations usually cause alterations in the biosynthetic routes of secondary metabolites modulating the final content of the compounds (Haslam, 1986). Such variations are very well illustrated in caffeine-containing plants where the content of this alkaloid may vary even in cultivars of the same species (Mazzafera et al., 1994).

Out of the 100 tested primers, 33 were selected for further studies on the basis of amplification patterns (Figure 1). These 33 profiles were analyzed in detail and it was observed that 18 primers (OPAC-1, OPAC-8, OPAC-10, OPAC-11, OPAC 12, OPAC-15, OPAC-17, OPY-20, OPAB-3, OPI-16, OPE-12, OPAL9, OPX-1, OPJ-1, OPZ-9, OPX-18, OPX-10 and OPX-7) revealed genetic polymorphismes. When this variation was compared with the results of total pilo-

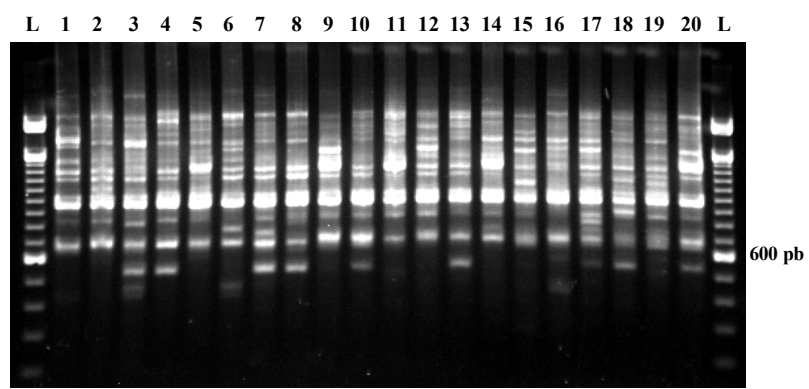

Figure 1 - Random Amplification of Polymorphic DNA (RAPD) amplification of twenty jaborandi genotypes using the primer OPX-18 from Operon Technology. Lateral lanes are $100 \mathrm{pb}$ ladder. The $600 \mathrm{pb}$ fragment is indicated.

carpine of the 20 jaborandi genotypes, it was observed that 9 of them (OPAC-1, OPAC-8, OPAC-10, OPAC11, OPAC12, OPAC-17, OPY-20, OPAB-3, OPX-18) could be used for selection of RAPD molecular markers to differentiate the 20 genotypes regarding their amounts of pilocarpine.

The molecular markers OPAC- $1_{800}$, OPAC- $8_{800}$ and OPAC- $11_{1000}$ were present in genotype 1 and absent in all other genotypes, therefore they might be considered as RAPD markers for these genotypes. Molecular marker OPAC- $8_{2000}$ presented polymorphism 
in all 19 tree genotypes but was not found in tree specimens of genotype 6 , which produce significant amount of pilocarpine and hence the absence of this particular DNA fragment could be treated as marker for this genotype. Molecular marker OPAC- $10_{1100}$ had a strong amplification in genotype 15 but was also observed in genotype 2 and 19, and these three genotypes have significant levels of pilocarpine. Similarly, OPAC- $12_{1100}$ had amplification in genotype 2, 15 and 19. OPAC $-17_{400}$ showed very good amplification in genotype 14 as well as in tree genotypes 2 and 7 . OPX-18 ${ }_{1200}$ was amplified only in tree genotype 7 and absent in all other 19 genotypes and hence could be selected as molecular marker for this highest pilocarpine producing genotype. Another fragment OPY$20_{725}$ was detected in genotype 2 and 19. It was also noticed that OPAB- $03_{550}$ was found only in the lowest pilocarpine producing genotype (4) and therefore it might be treated as molecular marker for this low pilocarpine producing tree.

Before collection for the analysis of pilocarpine and anthocyanin contents, the leaves had their length measured and a leaflet at the center of the composite was also measured. Only the third expanded leaf from the apex was used. One may argue that there might be an opposite relationship between leaf length and tree genotypes with low pilocarpine as seen for genotypes 7 and 2 with small leaves and high pilocarpine contents. However, group 3 showed the highest mean leaf length. Furthermore, genotype 1 with $232.5 \mu \mathrm{g} \mathrm{g}^{-1}$ of pilocarpine had a long leaf. At the other extreme, short leaves were those with the lowest contents. The correlation coefficient calculated for these characteristics were: pilocarpine $\times$ anthocyanin $=0.643$, pilocarpine $\times$ leaf length $=0.305$, pilocarpine $\times$ leaflet length $=$ 0.103 , anthocyanin $\times$ leaf length $=-0.113$, anthocya$\operatorname{nin} \times$ leaflet length $=0.06$, leaf length $\times$ leaflet length $=0.568$. Although a good relationship was observed between leaf and leaflet lengths, leaf length correlated better with pilocarpine. One may also argue that young leaves usually present more anthocyanin which decreases with aging. However, leaf length, that could also be an indication of leaf age, did not correlate well with anthocyanin. Furthermore, for all genotypes, leaves of the same age were used. Therefore, it seems that the anthocyanin content might not be correlated only to a developmental stage but also to genetic variability.

From the presence/absence (binary data) of the polymorphic loci the genetic similarity was calculated for the genotypes resulting in mean, minimum and maximum values of $0.66,0.51$ and 0.77 , respectively. The most similar genotypes were the genotype-pairs $\mathrm{J} 7 / \mathrm{J} 10, \mathrm{~J} 3 / \mathrm{J} 7, \mathrm{~J} 13 / \mathrm{J} 17, \mathrm{~J} 2 / \mathrm{J} 19$ and J10/J13 while the most different were $\mathrm{J} 1 / \mathrm{J} 6, \mathrm{~J} 4 / \mathrm{J} 15, \mathrm{~J} 4 / \mathrm{J} 18$ and $\mathrm{J} 8 / \mathrm{J} 9$. From the genetic similarities among the genotypes and using the hierarchic classification (UPMGA aggregation method) a dendogram was obtained (Figure 2) from which it was possible to define four main heterotic groups (A, B, C and D), represented by the genotypes J1 and J20 (A), J2, J3, J5, J7, J8, J10, J11, $\mathrm{J} 12$, J13, J14, J16, J17, J18, J19 (B), J9 and J15 (C) and $\mathrm{J} 4$ and $\mathrm{J} 6$ (D).

The results of the genetic diversity study using RAPD markers revealed four groups genetically distinct, suggesting a genetic structure. However, it was not possible to establish a relationship between the genetic diversity revealed by RAPD markers and pilocarpine and anthocyanin contents.

In a previous study, Moura et al. (2003) analysed several accessions from Maranhão e Pará states and showed a significant variation among the collection sites. Only individuals from a single place were grouped together with a great variation for the other accessions, indicating that jaborandi presents more variability among plants from the same area. They also analysed 10 accessions from the Merck farm and a mean similarity value of 0.72 was obtained. Such similarity varied from 0.55 to 0.91 when considering all the accessions.

The genus Pilocarpus has a wide distribution in the Brazilian territory, ranging from the northern state of Pará to the southern state of Rio Grande do Sul (Joseph, 1967) and P. microphyllus has been cited

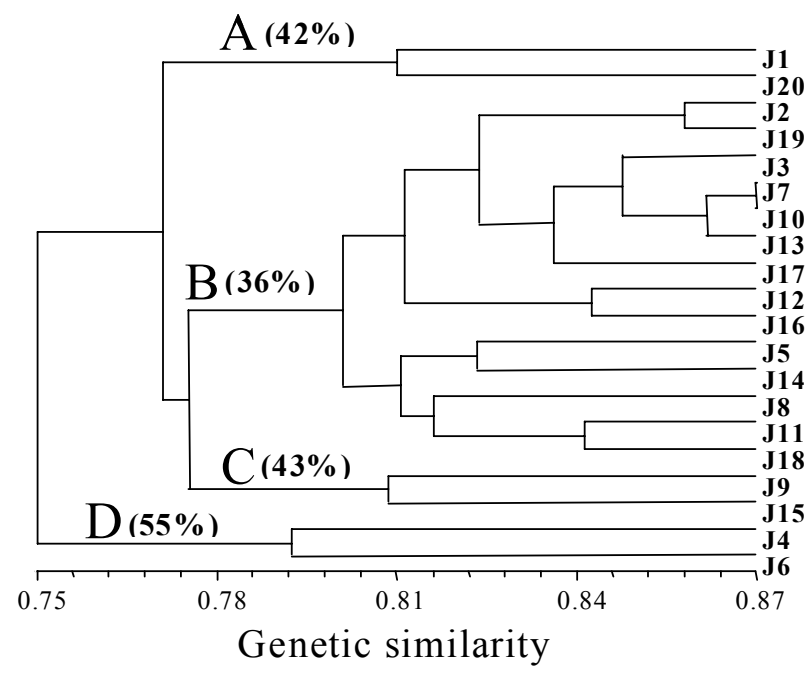

Figure 2 - Dendrogram unweighted pair-group method using arithmetical averages (UPGMA) obtained from similarity matrix based on DICE coefficient estimated among 20 jaborandi genotypes based on 170 Random Amplification of Polymorphic DNA (RAPD) markers. Values in parenthesis indicate the bootstrap values. 
to be more restricted to the northern state of Maranhão (Vieira, 1999; Pinheiro, 2002). Unfortunately, there is no information available on the reproductive mechanism of this species. P. microphyllus is hermaphrodite and although several plants presenting hermaphroditism have cross pollination due to different maturation times of pollen and stigma, it is not sure that this really happens with this species and that this could be the reason for the observed variation.

The differences observed among the 20 genotypes here studied indicate intra-specific genetic variability. Since these plants were grown under the same environmental conditions in a greenhouse, the genetic diversity observed is probably related to the collection sites these genotypes came from. Although these plants came from the same place, information (Pinheiro, 2002) indicates that there was no breeding program for the selection of the most productive plants in terms of alkaloid content. Therefore, the plants growing at the original farm may have been collected from different localities and genetic variation was probably maintained.

Molecular markers are more stable and informative than isoenzymes. They are currently used to study the genetic diversity of several species (Virk et al., 1995) and they can be used more efficiently to examine the genetic diversity of plant germplasm (Colombo et al., 2000). Although it was not possible to establish a direct relationship between RAPD molecular markers and pilocarpine content, it was observed that the presence or even the absence of some markers might be used to select plants that tend to accumulate more pilocarpine. Therefore, a study on the cosegregation of these markers and pilocarpine content could provide more information on their genetic linkage.

\section{ACKNOWLEDGEMENTS}

S.S. Sandhu thanks CNPq (Brazil) and TWASUNESCO (Italy) for the financial support to visit IAC, Campinas, Brazil. I.N. Abreu thanks for the pos-doctoral fellowship of FAPESP and P. Mazzafera thanks for the research fellowship of CNPq. This work was also partially granted by FAPESP and CNPq. To the Merek Company for providing the genetic material.

\section{REFERENCES}

ANDRADE-NETO, M.; MENDES, P.H.; SIlVEIRA, E.R. An imidazole alkaloid and other constituents from Pilocarpus trachyllophus. Phytochemistry, v.42, p.885-887, 1996.
AVANCINI, G.; ABREU, I.N.; SALDANA, M.D.A.; MOHAMED, R.S.; MAZZAFERA, P. Induction of pilocarpine formation in jaborandi leaves by salicylic acid and methyljasmonate. Phytochemistry, v.63, p.171-175, 2003.

COLOMBO, C.; SECOND, G.; CHARRIER, A. Diversity within American cassava germ plasm based on RAPD markers. Genetics and Molecular Biology, v.23, p.189-199, 2000.

DAVIES, A.N.; BROADLEY, K.; BEIGHTON, D. Xerostomia in patients with advanced cancer. Journal of Pain and Symptom Management, v.22, p.820-825, 2001.

DIXON, R.A.; PAIVA, N.L. Stress-induced phenylpropanoid metabolism. Plant Cell, v.7, p.1085-1097, 1995.

HASLAM, E. Secondary metabolism - fact and fiction. Natural Product Reports, v.3, p.217-249, 1986.

HOAGLAND, D.R.; ARNON, D.I. The water - culture method for growing plants whithout soil. Oakland: California Agriculture Experimental Station, 1950. 39p. (Circular, 347).

JOSEPH, C.J. Revisão sistemática do gênero Pilocarpus (ssp. brasileiras). Mecânica Popular, v.40, p.1-9, 1967.

MAZZAFERA, P.; CROZIER, A.; SANDBERG, G. Studies on the metabolic control of caffeine turnover in developing endosperms and leaves of Coffea arabica and Coffea dewevrei. Journal of Agricultural and Food Chemistry, v.42, p.1423-1427, 1994.

MIGDAL, C. Glaucoma medical treatment: philosophy, principles and practice. Eye, v.14, p.515-518, 2000.

MOURA, E.F.; PINTO, J.E.B.; SANTOS, J.B.; LAMEIRA, O.A.; BERTOLUCCI, S.K.V. Diversidade genética entre acessos de jaborandi (Pilocarpus microphyllus) por meio de marcadores RAPD. In: CONGRESSO NACIONAL DE GENÉTICA, 48, Caxambu, 2003. Resumos. Ribeirão Preto: Sociedade Brasileira de Genética, 2003.

PINHEIRO, C.U.B. Jaborandi (Pilocarpus sp., Tutaceae): a wild species and its rapid transformation into a crop. Economic Botany, v.51, p.49-58, 1997.

PINHEIRO, C.U.B. Extrativismo, cultivo e privatização do jaborandi (Pilocarpus microphyllus Stapf ex Holm.; Rutaceae) no Maranhão. Acta Botanica Brasilica, v.16, p.141-150, 2002 .

RABINO, I.; MANCINELLI, A.L. Light, temperature and anthocyanin production. Plant Physiology, v.81, p.922-924, 1986.

ROHLF, F.J. Numerical taxonomy and multivariate analysis system. Version 2.1. Owner manual. Port Jefferson: Applied Biostatistics, 2000. 38p.

SOUSA, M.P.; MATOS, M.E.O.; MATOS, F.J.A.; MACHADO, M.I.L.; CRAVEIRO, A.A. Constituintes químicos ativos de plantas medicinais brasileiras. Fortaleza: Editora da Universidade Federal do Ceará, 1991. 416p.

VIEIRA, R.F. Conservation of medicinal and aromatic plants in Brazil. In: JANICK, J. (Ed.) Perspectives on new crops and new uses. Alexandria: ASHS Press, 1999. p.152-159.

VIRK, P.S.; FORDLLOYD, B.V.; JACKSON, M.T.; NEWBURY, H.J. Use of RAPD for the study of diversity within plant germplasm collections. Heredity, v.74, p.170-179, 1995.

WALLER, G.R.; NOWACKI, E.K. Alkaloid biology and metabolism in plants. New York: Plenum Press, 1978. 293p.
Received June 20, 2005

Accepted July 21, 2006 